\title{
ANÁLISE ECONÔMICA DO USO DA BICICLETA EM CURITIBA
}

\author{
R. L. Witiuk ${ }^{1}$; B. Lemes ${ }^{2}$; F. B. von der Osten ${ }^{3}$ \\ ${ }^{1,2}$ Graduando do curso de Engenharia Civil da Pontificia Universidade Católica do Paraná \\ ${ }^{3}$ Professora do curso de Engenharia Civil da Pontifícia Universidade Católica do Paraná \\ bianca.lemesmacedo@gmail.com², rlwitiuk@gmail.com², fabiana.osten@pucpr.br ${ }^{3}$
}

Resumo: $\mathrm{O}$ modal cicloviário tem se popularizado nos grandes centros urbanos, sendo visto como uma alternativa de transporte barata, ecológica e saudável, mas que apresenta entraves de segurança e acessibilidade. A expansão aparentemente acelerada da quantidade de bicicletas na cidade de Curitiba tem chamado a atenção e levantado hipóteses de ordem econômica que tenham favorecido esse aumento. Desse modo, o presente estudo visa determinar o índice de correlação entre a variação da tarifa de transporte público, o preço da gasolina, e o número de ordens de serviço nas bicicletarias da cidade. Para tanto, será levantado os dados junto as bicicletarias e será desenvolvida uma metodologia de cálculo visando corrigir outras variáveis envolvidas na análise como os efeitos da crise econômica brasileira.

Palavras-chave: Modal cicloviário, Bicicleta, Transporte público.

\section{Introdução}

Como um meio alternativo de transporte nas grandes cidades, a bicicleta pode ser a melhor opção de locomoção para muitas pessoas. Apesar de existirem inúmeros outros motivos para utilizar a bicicleta como meio de transporte, o seu uso não é numericamente expressivo [1], comparado ao uso dos carros, nas grandes cidades do Brasil.

Com o aumento dos impostos sobre o combustível e da tarifa de transporte público em 0,55 centavos na capital paranaense, notou-se que a ocorrência de ciclistas nas ruas também aumentou. Sendo assim, o presente estudo tem como objetivo principal identificar a correlação entre a variação do aumento dos preços na gasolina e na passagem de ônibus com a variação dos serviços de manutenção e venda de bicicleta nas maiores bicicletarias de Curitiba. Esta análise permitirá determinar o perfil do ciclista curitibano quanto à motivação econômica para a utilização do transporte cicloviário.

\section{Metodologia}

Será realizado um levantamento de dados junto as maiores bicicletarias da capital paranaense. Tais dados serão cruzados com a variação do preço do combustível e da tarifa de ônibus em Curitiba de modo a obter o índice de correlação entre essas dispersôes. Será desenvolvida uma metodologia de cálculo visando corrigir outras variáveis envolvidas na análise como os efeitos da crise econômica brasileira. 


\section{Resultados esperados/Conclusóes}

A partir da correlação dos dados espera-se obter um grau de correlação alto entre as curvas calculadas, confirmando a hipótese que o aumento do combustível e da tarifa do transporte público em Curitiba estão correlacionados com um aumento da utilização da bicicleta como meio de transporte.

\section{Referências}

[1] SILVEIRA, Mariana Oliveira da. Mobilidade sustentável: a bicicleta como um meio de transporte integrado. 2010. 155 f. Dissertação (Mestrado) - Engenharia de Transportes, UFRJ, Rio de Janeiro, 2010. 